DOI: $10.5937 / \mathrm{MegRev} 2101023 \mathrm{D}$

Original scientific paper

Received 24.02.2021.

Approved 15.03.2021.

\title{
ACCOUNTABILITY IN THE CONTEXT OF COOPERATIVE GOVERNANCE AND LOCAL ECONOMIC DEVELOPMENT (LED) IN SOUTH AFRICAN LOCAL GOVERNMENT
}

\begin{abstract}
Provided the tensions and challenges found in different types of governance systems for developing clear objectives, effective policy implementation strategies, as well as monitoring and reporting mechanisms aimed at improving efficiency and sustainability of initiatives, this paper seeks to contribute to both theoretical and practical debates surrounding cooperative governance and LED. Whilst better policy outcomes that fit with local and differentiated needs among stakeholders may be one of the drivers for moving towards cooperative governance, there is a normative question of accountability. Does the common feature of flexible and adaptable arrangements in cooperative governance create accountability deficit, specifically promoting laissez-faire approach commonly associated with the implementation among role-players? This paper considers this question and the extent to which accountability may be ensured. To address these concerns data were collected from six municipalities in Western Cape, South Africa. A qualitative research design paradigm based on Interpretivists/Constructivists philosophy was employed. Data were collected through three data collection instruments, namely, document review, interviews and focus group discussions.

This paper argues that employing Key Performance Indicators as commonly used in the public service to promote accountability is difficult to enforce specifically in collaborative endeavours where participatory is voluntary. The paper recommends some accountability promotion enhancers. This will assist in improving the understanding of the context that may inhibit or enable stakeholders in taking full advantage of collaborative-led developmental interventions to further peoples' lives and to enhance their opportunities to partake in matters of development in their municipalities.
\end{abstract}

Keywords: LED, cooperative governance, Accountability, collaboration

Stellenbosch University, Cape Town. South Africa; dougrichy@gmail.com 


\section{Introduction}

The process of decision making in development matters at local government level in South Africa has moved over the past three decades, toward more inclusive and participatory process involving multiple stakeholders, specifically in this context, municipality, private and civil society. Given the complexities of modern era and the associated multi-dimensional challenges, municipalities alone can simply not succeed in the quest for successful LED, but that cooperative governance is an essential, if not irreplaceable components in this quest. Provided the common feature of flexible and adaptable arrangements in cooperative governance, concerns are raised regarding the extent to which ethos of accountability of role-players is upheld in collaborative governance. Many scholars have noted how the paradigmatic shift towards a polycentric system of governance is raising serious accountability concerns ${ }^{12} 345$. Because governance is no longer observed as an exclusive domain of government or civil society, but as an all-encompassing governance that incorporates both the contributions of civil society and the private sector ${ }^{6}$. Although the state continues its orthodox role of providing the enabling environment for the functions of the entire system and activities ${ }^{7}$. Put simply, government can no longer possesses the same kind of authority that traditionally has been ascribed to public entities. Therefore governing these interorganisational and multi-level networks creates new accountability challenges ${ }^{9}$.

Acar, M., Guo, C., \& Yang, K. (2008). Accountability when hierarchical authority is absent: views from public-private partnership practitioners. The American Review of Public Administration, 38(1), 3-23

2 Behn, R. D. (2001). Rethinking democratic accountability. Brookings Inst Press.

3 Page, S. (2004). Measuring accountability for results in interagency collaboratives. Public administration review, 64(5), 591-606.

4 Posner, P. L. (2002). Accountability Challenges of Third-Party Government. In The Tools of Government: A Guide to the New Governance, edited by Lester M. Salamon, 523-51. New York: Oxford University Press

$5 \quad$ Scott, C. (2006). Spontaneous Accountability. Public Accountability: Designs, Dilemmas and Experiences, edited by Michael W Dowdle, 174-94. Cambridge: Cambridge University Press

$6 \quad$ Kamara, R. D. (2017). Creating enhanced capacity for local economic development through collaborative governance in South Africa. Socio Economic Challenges, 1(3), 98-115.

7 Bristow, G., \& Healy, A. (2014). Building resilient regions: Complex adaptive systems and the role of policyintervention. Raumforschung und Raumordnung, 72(2), 93-102.

8 Dahan, N. M., Doh, J. P., \& Raelin, J. D. (2015). Pivoting the role of government in the business and society interfaceA stakeholder perspective. Journal of Business ethics, 131(13), 665-680.

$9 \quad$ Koliba, C. J., Mills, R. M., \& Zia, A. (2011). Accountability in governance networks: An assessment of public, private, and non-profit emergency management practices following Hurricane Katrina. Public Administration Review, 71(2), 210-220. 


\section{The importance of LED and cooperative governance in the municipal sphere}

LED is broadly associated with concerns of local control, use of local resources and locally determined intervention designed to create employment opportunities and to promote development ${ }^{10}{ }^{11}$. It contributes to the revitalisation of the local economy and the enhancement of local government fiscal efficiency $^{12}$. Phago ${ }^{13}$, cited in Kamara ${ }^{14}$; Seduma ${ }^{15}$ asserts that LED initiatives are not charitable endeavours but intend to inject the local economy with innovative business means such as community self-help services and entrepreneurial initiatives. LED present unique collaborating opportunities for inclusive representation and participation of local government, business and civil society in addressing matters of local concerns.

Given the complexities of the $21^{\text {st }}$ century, policymakers and development practitioners are increasingly perceptive to comprehend what mode of governance and forms of intervention might facilitate post-shock recovery (such as post COVID-19 and other economic woes) and protect local economies from future economic crises and unprecedented transformation ${ }^{16}$. These realities have paved way for the emergence of multi-stakeholders' approach of addressing multidimensional challenges that cannot be addressed by municipality alone. Given the expanded power afforded to the municipalities, municipalities alone can simply not succeed in the quest for successful LED, but that cooperative governance is an essential, if not irreplaceable components in this quest. Drawing

10 Nel, E. (2001). Llocal economic development: An Assessment of its current status in South Africa. Urban Studies, 38(7), 1003-1024.

11 Nel, E., Hill, T. R., \& Goodenough, C. (2007). Multi-stakeholder driven local economic development: Reflections on the experience of Richards Bay and the uMhlathuze municipality. Urban Forum, 18, 31-47.

12 Beyer, A., Peterson, C., \& Sharma, A. (2003). The Role of Participation and Partnerships in Local Economic Development in Africa. New York.: New York University's Robert Wagner Graduate School of Public Service

13 Phago, K. G. (2004). Reengineering and rethinking municipal service delivery through Local Economic Development (LED) initiatives. In Conference Paper presented at the 5th annual conference of SAAPAM held in Port Elizabeth (pp. 24-25). 43, pp. 238-252. Port Elizabeth : SAAPAM.

14 Kamara, R. D. (2015). Capacity building for local economic development: An evaluation of training initiatives in Cape Winelands district. Unpublished Masters dissertation. Port Elizabeth: Nelson Mandela Metropolitan University.

15 Seduma, M. P. (2011). The impact of Local Economic Development on the livelihood of communities in Ba-Phalaborwa Municipality, Mopani District, Limpopo Province, South Africa (Doctoral dissertation). Turfloop: University of Limpopo.

16 Bristow, G., \& Healy, A. (2014). Building resilient regions: Complex adaptive systems and the role of policy intervention. Raumforschung und Raumordnung, 72(2), 93-102. 
from the notion of the World Bank ${ }^{17}$, cooperative governance is conceptualised as multi-stakeholder's initiative and practice, combining diverse actors $v i s-\grave{a}$-vis, public, private and civil society to address matters of mutual concern for better and sustainable outcomes. Fundamentally, through cooperative governance, the key stakeholders are brought together with the hopes of facilitating cooperation and exchange while meaningfully bargaining over concerns of shared ideas and values.

In contextualising cooperative governance for LED through the lens of resilience, the study focuses mainly on the abilities of policies, strategies, systems and processes to foster cooperative governance regime adaptive to dynamic contextual drivers and internal processes, and sustainably allow for new development trajectories. Put simply, the ability of policy and legal framework and its implementation in promoting resilient shared capacity for local governance to cope with external socio-economic shocks ${ }^{18}$; successfully recover developmental pathways from shocks to its economy ${ }^{19}$; promote pluralistic adaptation to dynamic situations through mutual initiatives; and improve human ability to perceive change and influence future pathways.

In the theory of local development planning, two conflicting systems were identified - partial and integrated. The partial planning system has traditionally been autonomous state planning, which does not take into consideration all developmental factors of the local community. That is why this system of development planning has become less efficient but remains transitional especially in less developed countries. In contrast, the integrated system of local development planning has almost emerged in developed countries under the influence of science and the increasing influence of the non-governmental sector and citizens' initiative. New forms of specific partnerships with the state have made a special contribution to this process. This private-public partnership inevitably penetrates all other areas of the government ${ }^{20}$

Arguably cooperative governance is endowed with potential to improve system management and response to socio-economic challenges within municipalities to achieve sustainable appropriate development policy objectives aimed at sustainably developing its society. Provided this background this paper attempt to consider cooperative governance and LED as linked and nested and to integrate collaborative values in managing LED for change and sustainability.

$17 \quad$ World Bank (2014) Increasing the Effectiveness of Multi-Stakeholder Initiatives through Active Collaboration. Steyning: Wilton Park Conference Report.

18 Adger, W. N. (2000). Social and ecological resilience: are they related? Progress in human geography, 24(3), 347-364.

19 Hill, E., Wial, H., \& Wolman, H. (2008). Exploring regional economic resilience (No. 2008, 04). Working paper. Berkeley: Institute of Urban and Regional Development

20 Vukonjanski, I., Baltezarević, B., \& Vučeković, M. (2021). IT Approach to Integrated Local Development Planning, IPSI Transactions on Internet Research, Vol. 17, No. 1, 41-45. 


\section{Accountability in cooperative governance}

Accountability refers to the process by which decision-makers are held to account for their deeds and misdeeds. Behn (2001, p. 26), cited in Sørensen (2012, p. 2$)^{21}$ conceptualises accountability as an informal and formal relationship between an accountability holdee and an accountability holder that grants the latter the information and sanctioning powers needed to evaluate and subsequently punish or reward the former based on a mutually accepted set of standards. A more discernible definition of the concept is provided by Bovens $(2006, \text { p. } 9)^{22}$ as the "relationship between a stakeholder and a forum where the stakeholder should explain or justify his or her conduct, the forum can pose questions and pass judgement, and the stakeholder may encounter consequences". Collaborating to address socio-economic matters of mutual concern by multi-stakeholders requires some investments in mechanism aimed at ensuring accountability. This specific asset could assist in establishing trust and legitimacy to improve collaboration outcomes ${ }^{23} 24$.

\subsection{Factors to promote accountability}

In an attempt to elucidate the more decisive factors, promoting accountability in cooperative governance, the study deemed it necessary to consider those factors that are directly or indirectly connected to the structure, process and outcomes of LED and IGRs fora. These factors constitute the mechanism for mutual control within collaborative governance arrangements ${ }^{25}$. These factors are described in Table 1.

\subsection{Accountability for structure}

Sørensen (2012, p.13) maintains that collaborators must produce a collective account of the problem definitions that initiated the collaboration, the applied strategies for dealing with these problems. Successful collaboration requires a shift from the traditional hierarchical structure towards a decentralised, flexible,

21 Sørensen, E. (2012). Measuring the accountability of collaborative innovation. The Innovation Journal:. The Public Sector Innovation Journal, 2-18(1), 2-18.

22 Bovens, M. (2006). Analysing and assessing public accountability. A conceptual framework.

23 Cohen, W. M., \& Levinthal, D. A. (1990). Absorptive capacity: a new perspective on learning and innovation. Administrative Science Quarterly, 128-152.

24 Dyer, H. J., \& Singh, H. (1998). The Relational View: Cooperative Strategy and Sources of Interorganizational Competitive Advantage. Academy of Management Review, 23(4), 660-679.

25 Eun, J. (2010). Public accountability in collaborative governance: Lessons from Korean community centers. Retrieved November 26, 2019, from http://s-space.snu.ac.kr/bitstream/10371/68990/1/09_Jaeho_Eun.pdf.

Vol. 18, № 1, 2021: 23-42 
and more horizontal structure ${ }^{26}$. The horizontal structure fosters the emergence of the essential elements for collaboration, such as shared decision-making or open and direct communication. In designing an efficient collaborative endeavour, emphasis should be on governance structure promoting communication, shared accountability, and diversity while providing a high degree of organisational capacity is preferable.

Table 1: Factors influencing accountability in collaborative governance

\begin{tabular}{|c|c|c|}
\hline Category & Index & Description \\
\hline \multirow[t]{2}{*}{$\begin{array}{l}\text { Accountability for } \\
\text { structure }\end{array}$} & $\begin{array}{l}\text { Legal and regulatory } \\
\text { framework }\end{array}$ & $\begin{array}{l}\text { Clarity of law and regulation; obligation } \\
\text { of stakeholders to active participation } \\
\text { and pursuit of public interest; precise } \\
\text { description of tasks and work process } \\
\text { for stakeholders; Direct/indirect control } \\
\text { (sanction) power of stakeholders }\end{array}$ \\
\hline & $\begin{array}{l}\text { Institutional } \\
\text { Arrangement }\end{array}$ & $\begin{array}{l}\text { Representativeness of Stakeholders; } \\
\text { Expertise of Stakeholders }\end{array}$ \\
\hline $\begin{array}{l}\text { Accountability for } \\
\text { process }\end{array}$ & $\begin{array}{l}\text { Communication with } \\
\text { stakeholders through } \\
\text { a transparent and } \\
\text { democratic decision- } \\
\text { making process } \\
\text { through }\end{array}$ & $\begin{array}{l}\text { Transparency of decision-making process; } \\
\text { Democracy of Decision-making process; } \\
\text { Effort to communicate with Stakeholders } \\
\text { in the decision-making process; Clear } \\
\text { Descriptions of tasks and responsibility }\end{array}$ \\
\hline \multirow[t]{3}{*}{$\begin{array}{l}\text { Accountability for } \\
\text { Outcomes }\end{array}$} & $\begin{array}{l}\text { Performance } \\
\text { management }\end{array}$ & $\begin{array}{l}\text { Evaluation of performance and feedback } \\
\text { for performance by stakeholders and higher } \\
\text { Authority }\end{array}$ \\
\hline & $\begin{array}{l}\text { Reward and Incentive } \\
\text { system }\end{array}$ & $\begin{array}{l}\text { Scope of Achieved joint outcomes subject } \\
\text { to official criticism or recommendation for } \\
\text { collaborative accomplishment }\end{array}$ \\
\hline & & $\begin{array}{l}\text { Positive/negative incentive for voluntary } \\
\text { collaboration }\end{array}$ \\
\hline
\end{tabular}

Adapted from Kim, et al. (2004) ${ }^{27}$, cited in Eun (2010, p. 153)

Governance should be structured to guarantee balanced stakeholder interests as protection against domination and to encourage participation. Such a balance amongst stakeholder interest groups pursues to create open dialogue for knowledge exchange, negotiation, and methods improvement ${ }^{28}$. According

26 Henneman, E. A., Lee, J. L., \& Cohen, J. I. (1995). Collaboration: A concept analysis. Journal of Advanced Nursing, 21, 103 - 109.

27 Kim, S., No, I., \& Lee, M. (2004). Local revitalization and local NGO: Ensuring accountability in local NGO. The Study of Local Self-Governing.

28 UNDP. (2006). Multi-stakeholders engagement processes: A UNDP capacity development resources. Conference paper \#7. Retrieved April 11, 2018, from https://www.undp.org/con- 
to Purdy $^{29}$, laws and regulations are a social mechanism to predetermine the behaviours and interactions of all the involved stakeholders in collaborative endeavours. Legal and systematic tools should be clear, promoting accountability to effectively operate a governance system.

It is also worth mentioning here that the new theory of integral local planning, based on adequate social science, state and social partnership in this respect, is undoubtedly a revolutionary change not only in local planning but, consequently, in all other areas of public governance of a particular country. It is convincingly more effective than the long-ruling partial (elitist and narrow interest) state planning. In recent years, due to the strengthening of democratic forces, it has been primarily entering into some developed countries, while forms of partial local planning have remained in other countries. Thus, in view of the newly constituted science-based integral local planning theory, all countries should implement it in an organized manner. Yet, in its application, there are serious differences between developed and underdeveloped countries ${ }^{30}$

\subsection{Accountability for process}

Collaborative governance was conceptualised by some scholars as an interactive system and process based on the principle of interdependence ${ }^{3132} 33$. These processes promote individual liberty while maintaining accountability for collective decisions; advance political equality while educating citizens; foster a better understanding of competing interests while contributing to citizens' moral development and orient an atomised citizenry towards the collective.

The accountability of collaborative governance increases if the decisionmaking process is transparent and democratic, while communication is active to examine and reflect local peoples' needs and demands. They are the principal beneficiaries of goods and services that collaborative governance produces. The fairer the process of collecting opinions from multiple participants, the more collaborative the interaction becomes to reach a shared goal. Pethe, et al. (2011,

tent/dam/aplaws/publication/en/publications/capacity-development/drivers-of-change/ accountability/mul

29 Purdy, J. M. (2012). A Framework for Assessing Power in Collaborative Governance Processes. Public Administration Review, 72(3), 409-417.

30 31. Vukonjanski, I. (2019). The Substance and implications of integral Planning in local Government Unitis, Facta Universitatis, Series: Law and Politics, Vol. 17, No 3, 2019, pp 209-221

31 Kim, S., No, I., \& Lee, M. (2002). The comprehensive of governance. Seoul: Taeyoungmunhwasa.

32 Hong, S. (2004). Raising of collaborative local governance. The Study of Korean Public Administration, 1-19.

33 Suh, S. T., \& Min, B. G. (2005). A study on collaborative governance for regional development. Korean Journal of Regional Studies, 30(2), 25-44. 
p. 195$)^{34}$ explain that such a self-organising system would require the creation of a space and channels for communication and feedbacks between not only those who are agents within the said organisations but also with the citizens who are the ultimate beneficiaries of any improvements in the system. Purdy (2012, p. 411) indicates that processes for collaborative governance must be designed with flexibility to allow trial and error without creating ambiguity and confusion.

\subsection{Accountability for outcomes}

Collaborative governance is designed to promote mutual collaboration aimed at solving problems of mutual concern. Such an endeavour is reputed for providing prompt, effective and sustainable solutions to shared problems. Ample attention is accorded not only to the potential valued gain from the democratic nature of collaboration but the ability of the process to produce more efficient and effective outcomes than the vertical decision-making of an orthodox bureaucracy. Discourses on accountability for outcomes in collaborative governance are increasingly emerging as a critical factor. Klijn \& Koppenjan ${ }^{35}$ emphasise the need for role-players in collaboration to be held accountable, especially where concerns were raised about their performance and behaviour. Following the complexities associated with the collaborative arrangement, such as varied and conflicting needs and expectations of stakeholders, Ehren \& Godfrey (2017, p. 341$)^{36}$ maintain that accountability in collaboration is problematic. Kim, et al. (2004) mention that accountability for outcomes in collaboration could be enhanced by designing and implementing in the arrangement performance management and a proper reward and incentive system.

\section{Research design and methods}

To carry out the analysis on accountability of role-players in the existing fora (LED and Intergovernmental relations fora) within the six selected municipalities, an interpretive research design and specifically a case study approach was utilised. The research is located within the interpretive and constructivist paradigm, which reflects on definitions and pursues to understand the context and each case by using a range of qualitative approaches ${ }^{37}$. Employing interpretive

34 Pethe, A., Gandhi, S., \& Tandel, V. (2011). Assessing the Mumbai metropolitan region: A governance perspective. Economic and Political weekly, 187-195.

35 Klijn, E. H., \& Koppenjan, J. F. (2014). Accountable networks. T. he Oxford handbook of public accountability, pp.242-256.

36 Ehren, M. C., \& Godfrey, D. (2017). External accountability of collaborative arrangements; a case study of a Multi Academy Trust in England. Educational Assessment, Evaluation and Accountability, 29(4), 339-362.

37 Mouton, J. (2011). How to succeed in your masters \& doctoral studies: A South African guide and resource book. Pretoria: : Van Schaik. 
research design assists the researchers to understand the dynamics of policies and legal frameworks and as well as its implementation in promoting cooperative governance, that informs and fosters local economic development in selected six municipalities in Western Cape in their natural settings, and construct meanings that individual attached to their experiences ${ }^{38} 3940$.

In attempting to study the above-noted dynamics, a case study of six local municipalities were identified. These municipalities are Hessequa, Kannaland, Oudtshoorn, Mossel Bay, Swellendam and Theewaterskloof Municipalities. A mixed of factors were taken into consideration that assisted in an informed decision on the choice of municipalities suitable for comparative study. It can be maintained that there is no significant difference in the local economies of the six selected municipalities characterised by informal small businesses. The latter was another concern in the study, relating to concerns of inclusive participation of the private, civil society and government in the local governance and system management of LED within a municipality. The need to be able to match economic similarities between these comparing cases was another impetus for the selected municipalities.

The data collection instruments used for the investigation are key informant interviews, focus group discussions and documentary analysis. Semi-structured interviews were conducted with 24 key informants drawn from the six municipalities; District offices (Eden and Garden route); Western Cape Department of Economic Development and Tourism (DEDAT); Department of Cooperative governance and Traditional Affairs (CoGTA); NGOs/CBOs and business chambers in the District Municipalities. Specifically, the participants were: Executive Mayors and Councillors; LED and IDP staff; Officials of DEDAT, CoGTA and Salga; and Representatives of business and civil society.

Focus group discussions were facilitated with sixteen (16) participants which mostly involved the participation of the Mayors and the Mayoral committees of Hessequa and Theewaterskloof municipalities, and IDP staff of Garden Route (Eden) district municipality in George. Twenty (20) documents were analysed in the study to systematically assess the policy and legal framework that informs cooperative governance for LED in the selected six municipalities in the Western Cape. These were a mixture of relevant policy documents and implementation strategy documents retrieved from the public domain of the municipality, government department and public agencies. The predominant numbers of these documents were the municipality's IDP and the municipality's LED strategy and

38 Denzin, N. K., \& Lincoln, Y. S. (2005). Introduction: The discipline and practice of qualitative research. In N. K. Denzin, \& Y. S. Lincoln (Eds.), The sage handbook of qualitative research. Thousand Oaks, CA: Sage.

39 Esterberg, K. G. (2002). Qualitative Methods in Social Research. Boston: McGraw-Hill.

40 Jones, S. (2002). (Re)writing the word: Methodological strategies and issues in qualitative research. Journal of College Student Development, 43(4), 461-473. 
implementation plan. These were a mixture of relevant policy documents and implementation strategy documents.

The method of analysis chosen for this study to analyse the transcripts and organisational documents was a data-driven inductive approach of qualitative methods of thematic analysis aimed to identify patterns in the data employing thematic codes. Atlas.ti8.4.14 ${ }^{\mathrm{Ti}}$ software package was employed to extract, compare, explore, and aggregate the data to delineate the relationships amongst emerging themes ${ }^{41}$

\section{Results and discussions}

Accountability is established as one of the determinants for successful cooperative governance and LED. When the participants were asked to assess the level of accountability in their institutional arrangements, specifically LED and IGR forums, the findings are mixed. There is sense of accountability deficits among the role-players, indicating, municipality, private and the civil society to the collaboration outcomes. This assertion can be observed from the following response made by one of the municipal staff.

"On this one, like I said, there's a divergence. And when you're accountable, you observe entity as mine, you know! I'm a part of it. This platform can do better regarding that. But currently, it's not there and we just observe it as a municipal stuff". [D6]. ${ }^{42}$

Although there are certain mechanisms in place to promote accountability among the municipal role-players through performance assessment tools such as KPIs/KPAs. The good promise of KPIs/KPAs is being jeopardised by poor implementation as attested by one of the participants.

"There are some measures in term of our KPAs, where you need to be accountable”. [D6].

"Policy promotes accountability through its various measuring devices and measurement (KPI). In practice, it is a box tick exercise without real commitment and strong leadership from senior leaders". [D11]

Moreover, there is a concern that employing KPIs is difficult to enforce specifically in collaborative endeavours of this nature of LED, where participatory

$\overline{41} \quad$ Friese, S. (2019). ATLAS.ti 8.4 Windows Quick Tour update. Berlin, Germany:: Atlas. ti Scientific Software Development.

42 Document 6 . Transcribed document number as denoted by Atlas.ti 
is voluntary. Employing KPIs to promote accountability becomes less effective in an endeavour where roles and responsibilities of role-players are not defined.

The study established a gap in the theory and practice of Monitoring and Evaluation in the six municipalities which was found to be fundamentally based on a sharp focus on delivery targets, defined as outputs rather than outcomes (for example, the number of new set-up business, rather than the number of successful new business). This misplacement of priority tends to jeopardise the good intentions of monitoring and evaluation as it relates to cooperative governance and LED.

The study observed that although the ground-rule may be available in most of the municipalities, the question remains that the extent to which these ground rules are structured to promote and infuse accountability of role-players in LED oriented collaborative arrangement, became a concern. When the participants were asked to describe the mechanism that could promote shared accountability amongst the role-players (municipality, private and civil society). Most of the respondents believed in the agility of well-designed ground rules, which profoundly incorporates and articulates the roles and responsibilities of participating role-players, with the capabilities to deliver. McGuire $(2002)^{43}$; Koppenjan \& Klijn (2013) describe ground rules as the rules of the game or process rules as an added value, which assists in creating conditions enhancing interactions in a network to achieve good outcomes. These studies demonstrated the fundamentality of the ground rules, collaborating consistently with the research results. Most municipalities employ specific mechanisms, such as Terms of Reference (TOR), Memorandum of Understanding or partnership agreements. Others do not have any formal ground rules. Concerning the question of articulation of roles and responsibilities in the ground rules, the study established that several municipalities were found wanting. This may be the reason for the mediocre performance of some municipalities in LED fora and other associated institutional arrangements.

There're some mechanisms to promote shared accountability through service level agreements, memorandum of agreements". [D1]

Most participants believed in the power of providing authentic reporting and continuous engagement with role-players as an effective way of enhancing accountability. The following responses reflected this assertion:

"Continued external stakeholders' meetings/engagement are held and engagement continuously conducted, reports submitted to key stakeholders on regular basis". [D13; D19 and D23]

Accountability is promoted in an institutional arrangement (Forum) to guarantee balanced stakeholder interests in a manner that guide against undue dominance but promote participation through open engagement and dialogue

$43 \quad$ McGuire, M. (2002). Managing networks: Propositions on what managers do and why they do it. Public administration review, 52(5), 599-609. 
for knowledge exchange, negotiation and methods improvement (Jackson School Task Force, 2012, p. $12^{44}$ ). Arguably, accountability in cooperative governance improves when the decision-making process is open and inclusive of the trio, vis-à-vis, municipality, private and civil society. Dialogue consistently addresses and represents the interests and desires of the triumvirate (municipality, private and civil society) within the locality. The fairer the process of collecting input from various parties, the more constructive the relationship becomes in achieving a shared goal. Pethe, et al. (2011, p. 195) argue that such a self-organising system would require the creation of a space and channels for communication and feedbacks between agents within the said organisations and citizens as the ultimate beneficiaries of any improvement in the system.

Regarding the IGRs fora in the municipalities, the study established a certain element of ambiguities and duplication of roles and responsibilities where role-players hold similar roles, challenging for individuals to discern. Some of the participants believed that the structure and practice of intergovernmental relations were unclear in the manner where the roles and responsibilities of the three spheres of government are articulated in the collaborative management of the local economy. This assertion is reflected in the following responses:

"Clear sense of roles and responsibilities not understood and actioned by roleplayers affects IGR efforts negatively". [D4]

"This one of the problems associated with a situation where there's lack of proper term of reference. It makes things undefined and difficult to be formally held accountable". [D24]

A functional IGR structure requires the exigence for defined roles and responsibilities of the role-players at the various spheres of the government. The role-players need to understand their responsibilities and have the requisite capacity to perform assigned tasks efficiently and effectively. This will ensure achieving the objectives of the intergovernmental relations. This paper argue that this should be defined even where an overlap may exist, avoiding duplication of duties and to increase accountability for their actions. As maintained in the study, not one person can be justifiably held responsible for failure to comply with the bogus responsibilities

The findings of the study show that policy design is problematic in many ways, vis-à-vis, poor articulation of roles and responsibilities of key role-players in the existing policy and legal framework, outdated policy and legal framework,

44 Jackson School Task Force. (2012). Review of best practices for Multi-stakeholder initiatives: Recommendations for GIFT (Task Force Report). Retrieved July 20, 2018, from https://digital.lib.washington.edu/researchworks/bitstream/handle/1773/19669/M\%20Khagram\%20 Task\%20Force\%20Final\%20Report.pdf?sequence=1\&isAllowed=y 
fragmented and misaligned policy and legal framework; and lack of policy and legal framework assessment mechanism to establish how the policy and legal framework is doing on the ground.

Given the scholarship of Emerson \& Nabatchi, accountability also entails that a collaboration is meeting its objectives, first via the articulation of goals (to develop a plan or policy), then via the operationalisation of those goals ${ }^{45}$. Lastly, in order to measure compliance and performance, accountability also requires monitoring of substantive policy objectives and regulatory standards ${ }^{46}$

\section{Conclusion and recommendations}

This paper provides an overview of accountability in cooperative governance and LED by reviewing their definitions and strategies and their applications, and by critically assessing its conceptual coherence and their utility to promote development in local municipalities through collaborative endeavours, specifically LED and IGRs fora. Given the expanded role of municipalities regarding grassroots development, policy and legal framework urge the municipalities to partner with other stakeholders such as the private and the civil society to improve the system management and responsiveness to local needs within the municipalities. The study contends that the non-impressive derivatives of policy design and implementation, relating to promoting accountability in LED and IGRs fora aimed at development within municipalities, provided an impetus for its assessment. The dialectic between theory, policy formulation and practice of accountability in LED and IGRs fora within the six municipalities is discussed in the paper. Therefore, the paper concludes by providing the following recommendations:

\section{a) Reviewed LED Policy and legal framework}

The study identified LED policy and legal framework as outdated in meeting the realities and complexities of contemporary local government concerns. The existing LED national framework, Intergovernmental Relations Act and Policy on public participation should be reviewed and this should continually be carried out at least every 5 years to reflect the complexities of contemporary development concerns in a global and local context. Therefore, a reviewed policy framework and strategy for LED is one of the key determinants of success in collaborative governance for LED. The reviewed policy and legal framework should

45 Emerson, K., \& Nabatchi, T. (2015). Evaluating the productivity of collaborative governance regimes: A performance matrix. Public Performance \& Management Review, 38(4), 717-747.

46 Bardach, E., \& Lesser, C. (1996). Accountability in human services collaborative-For what? And to whom? Journal of Public Administration Research and Theory, 6(2), 197224. doi:10.1093/ oxford journals. jpart.a024307

Vol. 18, № 1, 2021: 23-42 
also incorporate the concerns regarding the specific roles and responsibilities of role-players in LED and IGRs fora, policy integration and coordination.

\section{b) Clearly defined roles and responsibilities of role-players}

The policy and legal framework should articulate the specific roles and responsibilities of role-players, municipality, private and civil society in LED fora. Similarly, the policy and legal framework should articulately define the roles and responsibilities of the respective sphere of government in IGR fora, especially where there are overlaps. This helps to mitigate the concerns of the laissez-faire approach commonly associated with implementation and thus promotes accountability among role-players.

In cooperative governance, the government should continue its orthodox role of providing an enabling environment for the functions of the entire system and activities, while the private sector generates jobs and income; use its resources and expertise to strengthen governance, monitoring and evaluation mechanisms. The civil society should improve on the delivery of services and mobilise individuals and community to engage actively in matters of shared developmental goal. The inclusion of civil society in the governance of development management becomes imperative as they pursue to play the active roles of shaping norms, laws, policies and tends to challenge traditional notions of representation, accountability, and legitimacy (Weiss, et al., 2013:13). Policy and legal documents should ensure that assigned roles and responsibilities are consistent/ compatible with the strengths and abilities of the role-player. This would help to minimize incapacity problems, which often lead to poor implementation, as observed in the study.

\section{c) Integration and coordination mechanism}

Reported cases of fragmented and uncoordinated approach could be mitigated by introducing measures aimed at facilitating coordination and alignment of policy and implementation of cooperative governance and LED (LED and IGRs fora) towards achieving better efficiency. Mechanism that can enhance the process through which the trio (municipality, private and civil society ) in LED fora share knowledge and information, having defined responsibilities and able to take joint decisions aimed at achieving a greater common goal. The paper also recommends similar mechanism for integrating plans, strategies and procedures of IGRs fora.

\section{d) Monitoring and Evaluation}

There is a need for increased monitoring and evaluation capability to provide feedbacks on theory and practice of cooperative governance and LED within the 
municipalities aimed at identifying cases of good practice which have to be replicated and areas of deficiencies that need to be improved. Adequate budgetary provision set aside for the assessment of the enabling policy and its implementation. The paper also recommend that M\&E should be more of outcome-based rather focussing on output.

\section{e) Legitimacy of purpose}

The municipality, private and civil society pursues to collaborate for a shared purpose, either to resolve problems/challenges or to take advantage of opportunities. Noteworthily, no matter the driving force behind any collaboration, to be effective in achieving its unifying purpose, the collaboration should be characterised with a sense of legitimacy and clarity of purpose, strategies and action well-articulated to the various stakeholders. Having a legitimate sense of purpose is an essential requirement for building a collaborative culture. Legitimacy could be conceptualised as a generalised perception that the actions of a collaborating entity are desirable, proper, or within some system of norms, beliefs, and definitions (O'Leary \& Vij, 2012:514). Put differently, a sense of purpose assists the role-players to feel connected to the collaboration and assists to ensure that role-players present their best because they want to, not because they need to.

\section{f) Communication plan}

Effective communication between municipalities, private and civil society, as well as between the three branches of government, is reported in the study as a key requirement for the productive performance of LED and IGRs fora respectively. Communication plan is recommended where various channels, ensuring effective communication are structured, enhancing communication between role-players in LED and IGRs fora.

\section{g) Good governance}

Good governance relates to the ability of LED and IGRs fora to achieve appropriate development policy objectives, aimed at sustainably developing its society. Good governance centres on how efficiently resources are allocated and managed, directed by accountable role-players in LED and IGRs fora, and executed by a resolute teamof professionals collectively to address socio-economic concerns within municipalities. The study recommends good governance that is characterised by specific features, such as participatory, consensus orientation, accountability, transparency, unbiasedness, responsiveness, inclusiveness, and compliance to the rule of law 


\section{h) Ground rules}

The ground-rule contains the dos and don'ts aimed to regulate the behavioural conduct of role-players in LED fora (municipality, private and civil society) and IGRs fora. The ground rules should amongst other things defined the specific roles and responsibilities of key role-players, institutional structure and the how meetings and reporting should be conducted. It is recommended in the paper that ground rules should reflect the input and concerns of the trio, vis-àvis, municipality, private sector and civil society in LED fora. Regarding the IGRs fora similar recommendation of the ground rule is advanced, where the input and concerns of the sub-national government are reflected in the ground rule.

\section{Reference}

- Acar, M., Guo, C., \& Yang, K. (2008). Accountability when hierarchical authority is absent: views from public-private partnership practitioners. The American Review of Public Administration, 38(1), 3-23.

- Adger, W. N. (2000). Social and ecological resilience: are they related?. Progress in human geography, 24(3), 347-364.

- Babbie, E., \& Mouton, J. (2001). The Practice of Social Research. Cape Town: Oxford University Press

- Bardach, E., \& Lesser, C. (1996). Accountability in human services collaboratives-For what? And to whom? Journal of Public Administration Research and Theory, 6(2), 197-224. doi:10.1093/ oxfordjournals.jpart.a024307

- Behn, R. D. (2001). Rethinking democratic accountability. Brookings Inst Press.

- Beyer, A., Peterson, C., \& Sharma, A. (2003). The Role of Participation and Partnerships in Local Economic Development in Africa. New York.: New York University's Robert Wagner Graduate School of Public Service.

- Bovens, M. (2006). Analysing and assessing public accountability. A conceptual framework. European Governance Papers (EUROGOV) No. No. C-06-012006.

- Bristow, G., \& Healy, A. (2014). Building resilient regions: Complex adaptive systems and the role of policy intervention. Raumforschung und Raumordnung, 72(2), 93-102.

- Buchholz, R. A., \& Rosenthal, S. B. (2004). Stakeholder theory and public policy: How governments matter. Journal of Business Ethics, 51(2), 143-153.

- Cohen, W. M., \& Levinthal, D. A. (1990). Absorptive capacity: a new perspective on learning and innovation. Administrative Science Quarterly, 128-152.

- Dahan, N. M., Doh, J. P., \& Raelin, J. D. (2015). Pivoting the role of government in the business and society interface: A stakeholder perspective. Journal of Business ethics, 131(13), 665-680.

- Denzin, N. K., \& Lincoln, Y. S. (2005). Introduction: The discipline and practice of qualitative research. In N. K. Denzin, \& Y. S. Lincoln (Eds.), The sage handbook of qualitative research. Thousand Oaks, CA: Sage. 
- Dyer, H. J., \& Singh, H. (1998). The Relational View: Cooperative Strategy and Sources of Interorganizational Competitive Advantage. Academy of Management Review, 23(4), 660-679.

- Ehren, M. C., \& Godfrey, D. (2017). External accountability of collaborative arrangements; a case study of a Multi Academy Trust in England. Educational Assessment, Evaluation and Accountability, 29(4), 339-362.

- Emerson, K., \& Nabatchi, T. (2015). Evaluating the productivity of collaborative governance regimes: A performance matrix. Public Performance \& Management Review, 38(4), 717-747.

- Esterberg, K. G. (2002). Qualitative Methods in Social Research. Boston: McGraw-Hill.

- Henneman, E. A., Lee, J. L., \& Cohen, J. I. (1995). Collaboration: A concept analysis. Journal of Advanced Nursing, 21, 103 - 109.

- Hill, E., Wial, H., \& Wolman, H. (2008). Exploring regional economic resilience (No. 2008, 04). Working paper. Berkeley: Institute of Urban and Regional Development.

- Hong, S. (2004). Raising of collaborative local governance. The Study of Korean Public Administration, 1-19

- Jackson School Task Force. (2012). Review of best practices for Multi-stakeholder initiatives: Recommendations for GIFT (Task Force Report). Retrieved July 20, 2018, from https://digital.lib.washington.edu/researchworks/bitstream/ handle/1773/19669/M\%20Khagram\%20Task\%20Force\%20Final\%20Report. pdf?sequence $=1 \&$ isAllowed $=y$

- Jones, S. (2002). (Re)writing the word: Methodological strategies and issues in qualitative research. Journal of College Student Development, 43(4), 461-473.

- Kamara, R. D. (2015). Capacity building for local economic development: An evaluation of training initiatives in Cape Winelands district. Unpublished Masters dissertation. Port Elizabeth: Nelson Mandela Metropolitan University.

- Kamara, R. D. (2017). Creating enhanced capacity for local economic development through collaborative governance in South Africa. Socio Economic Challenges, 1(3), 98-115.

- Kim, S., No, I., \& Lee, M. (2004). Local revitalization and local NGO: Ensuring accountability in local NGO. The Study of Local Self-Governing.

- Kim, T. B. (2010). Collaborative Governance for Sustainable Development in Urban planning in South Korea (Unpublished Doctoral Dissertation). Birmingham,: University of Birmingham, United Kingdom.

- Klijn, E. H., \& Koppenjan, J. F. (2014). Accountable networks. T. he Oxford handbook of public accountability, pp.242-256

- Koliba, C. J., Mills, R. M., \& Zia, A. (2011). Accountability in governance networks: An assessment of public, private, and nonprofit emergency management practices following Hurricane Katrina. Public Administration Review, 71(2), 210-220. 
- McGuire, M. (2002). Managing networks: Propositions on what managers do and why they do it. Public administration review, 52(5), pp. 599-609.

- Mashaw, J. L. (2006). Accountability and institutional design: Some thoughts on the grammar of governance. Public Law Working Paper, (116), 115-156.

- Nel, E. (2001). Llocal economic development: An Assessment of its current status in South Africa. Urban Studies, 38(7), 1003-1024.

- $\quad$ Nel, E., Hill, T. R., \& Goodenough, C. (2007). Multi-stakeholder driven local economic development: Reflections on the experience of Richards Bay and the uMhlathuze municipality. Urban Forum, 18, 31-47.

- O'Leary, R., \& Vij, N. (2012). Collaborative Public Management: Where Have We Been and Where Are We Going? The American Review of Public Administration, 42(5), 507-522.

- Page, S. (2004). Measuring accountability for results in interagency collaboratives. Public administration review, 64(5), 591-606.

- $\quad$ Pethe, A., Gandhi, S., \& Tandel, V. (2011). Assessing the Mumbai metropolitan region: A governance perspective. Economic and Political weekly, 187-195.

- Phago, K. G. (2004). Reengineering and rethinking municipal service delivery through Local Economic Development (LED) initiatives. In Conference Paper presented at the 5th annual conference of SAAPAM held in Port Elizabeth (pp. 24-25). 43, pp. 238-252. Port Elizabeth : SAAPAM.

- Posner, P. L. (2002). Accountability Challenges of Third-Party Government. In The Tools of Government: A Guide to the New Governance, edited by Lester M. Salamon, 523-51. New York: Oxford University Press.

- Purdy, J. M. (2012). A framework for assessing power in collaborative governance processes. Public administration review, 72(3), 409-417.

- Scott, C. (2006). Spontaneous Accountability. Public Accountability: Designs, Dilemmas and Experiences, edited by Michael W Dowdle, 174-94. Cambridge: Cambridge University Press.

- Seduma, M. P. (2011). The impact of Local Economic Development on the livelihood of communities in Ba-Phalaborwa Municipality, Mopani District, Limpopo Province, South Africa (Doctoral dissertation). Turfloop: University of Limpopo.

- Sørensen, E. (2012). Measuring the accountability of collaborative innovation. The Innovation Journal:. The Public Sector Innovation Journal, 2-18(1), 2-18.

- Suh, S. T., \& Min, B. G. (2005). A study on collaborative governance for regional development. Korean Journal of Regional Studies, 30(2), 25-44.

- $\quad$ Ulibarri, N., Emerson, K., Imperial, M. T., Jager, N. W., Newig, J., \& Weber, E. (2020). How does collaborative governance evolve? Insights from a medium-n case comparison. Policy and Society, 39(4), 617-637.

- UNDP. (2006). UNDP. 2006. Multi-stakeholders engagement processes: A UNDP capacity development resources. Conference paper \#7. Retrieved April 11, 2018, from https://www.undp.org/content/dam/aplaws/publication/en/publications/capacity-development/drivers-of-change/accountability/mult 
- Vukonjanski, I. (2019). The Substance and implications of integral Planning in local Government Unitis, Facta Universitatis, Series: Law and Politics, 19(3), pp 209-221.

- Vukonjanski, I., Baltezarević, B., \& Vučeković, M. (2021). IT Approach to Integrated Local Development Planning, IPSI Transactions on Internet Research, 17(1), pp41-45.

- World Bank (2014) Increasing the Effectiveness of Multi-Stakeholder Initiatives through Active Collaboration. Steyning: Wilton Park Conference Report. 
DOI: 10.5937/MegRev2101023D

Originalni naučni rad

Primljen 24.02.2021.

Odobren 15.03.2021.

\section{ODGOVORNOST U KONTEKSTU KOOPERATIVNOG UPRAVLJANJA I LOKALNOG EKONOMSKOG RAZVOJA U JUŽNOAFRIČKOJ LOKALNOJ UPRAVI}

Apstrakt: $U$ uslovima napetosti $i$ izazova koji se nalaze u različitim vrstama sistema upravljanja za razvijanje jasnih ciljeva, efikasnih strategija sprovodenja politike, kao i mehanizama praćenja $i$ izveštavanja usmerenih na poboljšanje efikasnosti $i$ održivosti inicijativa, ovaj rad nastoji da doprinese i teorijskim i praktičnim raspravama oko zadružnog upravljanja i LED (Lokalni ekonomski razvoj). Iako bolji ishodi politike koji se uklapaju sa lokalnim i diferenciranim potrebama medu zainteresovanim stranama mogu biti jedan od pokretača kretanja ka zadružnom upravljanju, postoji normativno pitanje odgovornosti. Da li zajednička karakteristika fleksibilnih i prilagodljivih aranžmana u zadružnom upravljanju stvara deficit odgovornosti, posebno promovišući laissez-faire pristup koji je uobičajeno povezan sa primenom među igračima uloga? Ovaj rad razmatra i pitanje u kojoj meri može biti osigurana odgovornost. Da bi se rešili ovi problemi, prikupljeni su podaci iz šest opština zapadnog rta u Južnoj Africi. Korišćena je paradigma kvalitativnog istraživačkog dizajna zasnovana na filozofiji Interpretivisti / Konstruktivisti. Podaci su prikupljeni putem tri instrumenta za prikupljanje podataka: pregledom dokumenata, intervjuima i diskusijama u fokus grupama.

Ovaj rad iznosi tvrdnju da je korišćenje ključnih indikatora učinka koji se često koriste u javnim službama za promovisanje odgovornosti, teško primeniti posebno u zajedničkim poduhvatima gde je participacija dobrovoljna. Članak preporučuje neke pojačivače unapređenja odgovornosti koji će pomoći u poboljšanju razumevanja konteksta koji može inhibirati ili omogućiti zainteresovanim stranama da u potpunosti iskoriste razvojne intervencije vođene saradnjom u daljem životu ljudi i poboljšati njihove mogućnosti da učestvuju u pitanjima razvoja u svojim opštinama.

Ključne reči: Lokalni ekonomski razvoj, zadružno upravljanje, odgovornost, saradnja 